\title{
REPRESENTATION OF ROMA IN LITHUANIAN ONLINE MEDIA: 15MIN.LT AND LRYTAS.LT CASE STUDIES
}

\author{
Rūta Sutkutè \\ Department of Public Communication \\ Vytautas Magnus University \\ 58 K. Donelaičio g., Kaunas, Lithuania, 44248 \\ ruta.sutkute@stud.vdu.lt
}

\begin{abstract}
This study focuses on how Roma communities are represented in the Lithuanian online media. The aim is to answer the question of how news about the Roma is embedded in the broader practices of neoliberalism and racist discourses. Representation of the Roma in the media is inseparable from constructivism, power and influence. Roma communities have little opportunity to make their voices heard in society, i.e., their voice is not heard or represented in the media. Political representation of the Roma is particularly important due to the weak opportunities to participate in the formulation and decision-making of certain political decisions, both in the national and international context. It is assumed, that the negative and even stereotypical portrayal of the Roma in the media encourages a negative public attitude towards this ethnic group and has an impact on the (in) successful integration of the Roma into society.

The aim of the research is to find out how Roma are represented on the online news portals 15 min.lt and Lrytas.lt and to reveal how stereotypes are formed in relation with this national minority. The following tasks are used to reveal the aim of the work: to present the history of the Roma and the problems of their identity, to analyze the concept of Romaphobia, to present the theory of social constructivism and the role of the media in shaping social reality; to perform a qualitative analysis of the content of the news portals 15min.lt and Lrytas.lt: comparing how Roma perceptions are formed on these news portals and how different groups of actors contribute to constructing and maintaining stereotypes in the media/society.

The qualitative analysis of the content revealed that the information, provided in the media, aims to portray the Roma as a threat to public security and to the local population, who experience socio-economic exclusion, who have different values and are reluctant to integrate. However, Roma are not given the right to self-representation because the unilateral narrative of the event dominates and the audience for which the report is addressed is too homogeneous. Manifestations of Romaphobia are observed in the news portals' discourse. It can be assumed, that this creates a negative value orientation for readers, as Roma is perceived as an "undesirable" ethnic group in Lithuania. However, the Roma themselves do not have effective means to make heard their "voice" and participate in public life in order to challenge the dominant negative images.

Keywords: Romaphobia, Roma, Media Representation, Stereotypes, Stigmatization, Political Identity, Gypsies, Romani people, Exclusion, Outgroup.
\end{abstract}

DOI: $10.21303 / 2504-5571.2020 .001529$

\section{Introduction}

Recently, too little attention has been paid to research on the media representation of certain social groups, such as the Roma. This article presents a study, aimed at uncovering the reproduction of stereotypes in the media. The construction of identity is inseparable from power and the desire to dominate. Segregation between ethnic minorities and the majority of the population plays an important role in shaping the state's domestic and foreign policies. Today, there is an increasing return to criticism of ethnic minorities and their representation in the media, which is why the relevance of the issue is unquestionable.

According to the 2011 census, there are 2115 Roma people living in Lithuania (compared to 2571 in 2001) [1]. Since 2000 various plans are being prepared for the integration of Roma into Lithuanian society $[2,3]$. The aim of the plans is to promote integration of the Roma community into the education system, to increase their access to health services and labor market, to increase women's employment rate in the Roma community, and to promote intercultural dialogue. However, Roma inclusion and integration policies and efforts had to face negative societal attitudes towards Roma people in the society. Negative public perceptions towards the Roma community hamper some Government reforms, related to Roma integration. It is assumed, that in order for the 
Roma integration plans to be implemented, it is necessary to change the negative attitudes of the society towards the Roma community.

Attitudes towards the Roma ethnic group have not changed and remained one of the most negative since 2005, when public opinion polls on national minorities were launched. 2016 the results of the public opinion poll showed that over $63.8 \%$ would not want to live in the neighborhood with the Roma, $45.3 \%$ would not work at the same workplace. According to the data of the 2017 survey, $63.8 \%$ would not want to live in the neighborhood with the Roma, $47.6 \%$ would not want to work at the same workplace, and $61.9 \%$ would not to rent a flat in the same apartment [4]. According to the results of the public opinion poll of 2019, the Roma community continues to be the most disadvantaged ethnic group in Lithuania. $63 \%$ of respondents would not like to live with the Roma in the neighborhood, $39 \%$ would not like to work at the same workplace, $61.9 \%$ would not to rent a flat in the same apartment [5].

Thus, Lithuanian Roma face negative prejudices in many areas of life (education, labor market, social status, health care, etc.). Roma integration is also hampered by the difficulty of society in accepting foreigners. This was compounded by the silent discussions about the largest Roma Tabor in Lithuania (located near the capital), which has been an unsolvable problem for many years [6]. The government has tried to solve the problems, faced by the Lithuanian Roma, but in order to reduce the exclusion of the Roma in society, it is necessary to mitigate the negative public attitude towards the Roma.

The literature addresses Roma exclusion by touching on various policy areas, such as housing, education, employment, or social protection [7-9]. Different perceptions of the Roma community in society pose problems for the inclusion and exclusion of Roma communities. The media is dominated by negative associations involving Roma, and the Roma themselves do not have the effective means to represent their "voice" and participate in public life in order to challenge the prevailing negative stereotypes in various countries across Europe. This is particularly evident in these studies [10-13], which examine the possibilities of political representation of Roma, relations with identity, their representations in various discourses.

However, regarding the Lithuanian context, the role of the media in representing the Roma and forming a negative image in Lithuanian society was not given enough attention. Therefore, the main problem of this research is the stereotypical depiction of Roma in Lithuanian online media. It is assumed, that the media, as a powerful public information mechanism reaching a large part of the population, becomes the main source of information, opinion and attitude formation about minority groups, therefore this article presents a study on Roma representation in Lithuanian online media channels.

The aim of this work is to find out how the Roma community is represented on the online news portals 15 min.lt and Lrytas.lt and to reveal how stereotypes are formed regarding this national minority. The following goals are used to reveal the purpose of the work: 1) to present the history of the Roma people and the problems of their identity, to analyze the concept of Romaphobia, to present the theory of social constructivism and the role of the media in shaping social reality; 2) to perform a qualitative analysis of the content of the news portals 15min.lt and Lrytas.lt: 3) compare how the content, related to Roma people, is formed on these portals and how different actors contribute to the construction and maintenance of stereotypes in the media/society.

\section{Methods of the Study}

Theoretical and empirical research methods were used to implement the tasks. The analysis of news coverage on Roma people uses qualitative analysis of the content of media reports. Comparative analysis is also used, which helps to reveal how certain groups of actors construct and/or represent the perceptions of Roma people in Lithuania on different news websites.

\section{Theoretical Background}

\section{1. A Brief History and Issues of Roma Identity}

The Roma genocide, which was perpetrated by Nazi Germany, is known as Porrajmos (a catastrophe similar to the Hebrew term Shoah). However, there is still not enough research into 
the "massacres" of the $20^{\text {th }}$ century. Some historians even deny that it was a massacre. If we had recourse to the 1948 Convention on the Prevention and Punishment of the Crime of Genocide, one might have some doubt. The definition refers to the intensity of the destruction of an ethnic, national, or racial group, in whole or in part. One can remember the Arrow Cross regime in Hungary (the Nyilas) or the Antonescu dictatorship in Romania, as well as the Slovak Puppet regime, which supported and joined this policy. The ethnicity of the Roma has always raised many questions from their arrival in medieval Europe to the present day. Remembering the history of persecution and genocide in Nazi times is important for a better understanding of the situation of the Roma people in today's European society. Because researchers still emphasize the continuity of preconceived negative approaches [14]. Current indicators of social integration in Europe also raise the question of the (in) successful integration of the Roma in their (non-) host societies. Thus, there remains a need to answer questions, related to Roma identity, the creation of myths and their representation in media. In order to achieve the main goal of the research, this work will be based on the theoretical approach of social constructivism.

The Roma population in Europe is estimated by the European Commission to be between 10 and 12 million [2]. The largest Roma communities are located in the Balkans, as well as in South America, the former Soviet Union countries, and in Central and Western Europe. There are countries with a Roma population of about 1 million, such as Spain, Romania, the United States and Turkey. However, Roma integration can be described as slow across many countries. In some EU countries, they have been denied access to education for a long time [3]. And in some communist states, the Roma people were forced to live sedentarily with the locals. This has led to social and cultural conflicts. In many countries, Romani people have been persecuted, leading to their migration and isolation [14]. In 1971 The first World Roma Congress took place in London, in which the Romani flag and Romani anthem were adopted. The Congress made a call to UN member states to recognize the Romani people as a separate nation and to treat them as a national minority [15].

The Roma came to Lithuania around middle of $15^{\text {th }}$ century. Their immigration was prompted by the persecution of the Roma in the $15^{\text {th }}$ and $17^{\text {th }}$ centuries and by the restrictions and violations of their human rights in Europe. In Lithuania, the Roma were given the right to move freely from place to place. 1918-1940 Roma were treated as full citizens of Lithuania. However, about 500 Romani people (one in every three Lithuanian Roma) were killed during the Nazi occupation. Meanwhile, about 1,000 Roma were deported to forced labor. During the Soviet period, the situation of the Roma in Lithuania was difficult [16].

It is important to distinguish how Roma identity is seen/understood by others; and the opportunities for the Roma to express their voice. For this reason, this article deconstructs the (in) ability of Roma to represent themselves in the media. It is assumed, that the opportunities for Roma to participate in public life are severely limited in the political and social context. The author does not assess whether such representations are "true" or "incorrect". The aim of the article is to objectively investigate whether negative prejudices are formed in the media, to reveal the main actors, involved in the discourse (opportunities for Roma self-representation), to identify Roma identities, to determine whether such representations help or hinder the inclusion/integration or exclusion of Roma communities. Full inclusion means social, cultural, economic, political or even legal integration in public life. It is a form of citizenship and a requirement for the full recognition of the Roma as a full member of society and its active participation and involvement [17].

There are major disagreements among academics, exploring Roma identities on ontological questions such as "who are the Roma?" [18] argue that there are various definitions of what constitutes Roma identity. However, there are no objective criteria to define exactly who the Roma are, as not all Roma speak the same language or have a common religion, as they are geographically dispersed, live in different economic and political conditions, have different levels of education or even cultural practices. The fact of Romani people being a very heterogeneous community across the world is quite widely acknowledged among academicians. It is agreed, that it is even difficult to use a single common name that covers all individuals or communities, belonging to the Roma. In addition, the origin of the Roma people (India) has provoked a particularly "heated" debate among academicians [19] in discussing when and why the Romani people left India. 
It is acknowledged that over-emphasis on Roma diversity is very ingrained in society [11]. The various perceptions of the Roma people help to emphasize their difference as "others" in society. For this reason, the article discusses how the representation of Roma on online news portals contributes to the formation of certain values in society, and at the same time can contribute to the formation of Roma inclusion or exclusion policies (employment, housing, education, etc.). Because any policy requires the active participation of Romani people in public life, as well as a "voice" or opportunities for self-representation in the media. Looking at the various media and their content in Europe, it is not difficult to find articles regarding the "problems", caused by Roma people in major European cities or their alleged crime. There are many perceptions, related to Roma people, that describe them as nomads, criminals, beggars, retarded, uneducated, dangerous, drug-related, victims, and so on [17]. Roma communities both in Lithuania and in other European countries are quite "visible", but often in a negative context.

The portrayal of the Roma as a problematic community is historically justified to provide a base for their assimilation, persecution, marginalization, or even genocide. Negative images of the Roma are more than a historical artifact. Links can be found between the negative political discourse towards the Roma and their subsequent hostile policies (Roma eviction) [20]. Such policies are often linked to a security discourse, in which the Roma are perceived as a threat to society and thus justify even their deportation within a certain period of time (the French case of Roma, who did not and could not find work within a certain period) [21]. The negative representation of the Roma has an impact on the state's policy towards this national minority. Therefore, this article assumes that negative representation in the media is also conducive not only to the formation of hostile policies towards the Roma, but also to the formation of stereotypes in society, which only further complicates the opportunities for Roma integration.

\section{2. Romaphobia - a New Concept, an Old Fear?}

In the media, Roma people are often portrayed as criminals, living in ghettos and often in conflict with "indigenous" people. The message sent is often directed at a particular phenomenon of fear. The representation of the Roma in the media is often one-sided. Negative headlines eventually became self-acceptable and subconsciously accepted by readers [22]. State-sanctioned forced evictions, threats against Roma communities in Europe are quite common [23]. Extreme groups have received a lot of attention, with Roma as their main target. The media reacted to these attacks in a very ambiguous way, as the victims were blamed and not members of extremist groups, who committed crimes [24]. Meanwhile, in Lithuania, the then mayor of Vilnius in 2014 sought to start the rapid eviction of Roma from the Tabor, stating that the municipality seeks to solve the problems of Roma integration. For several years, the aim was also to demolish illegally constructed houses in a Roma camp on the southern outskirts of the capital (for example, 3 illegally constructed buildings were demolished in 2012) [6].

For several years now, there has been a debate about the concept of "(un) new" Romaphobia, which relates not only to ethnicity, but also to a certain identity or its formation. Researchers on ethnic minority issues argue that Roma are often the object of politicization, both in politics and in the media, marginalized and demonized [25]. Often, they even "serve" the politics of labeling [26]. This is particularly useful in constructing a distinction between the inner and outgroup in a society where the Roma constitute a small national minority. The term "Roma" is often used as a homogenizing category for very heterogeneous groups with different languages, identities and social statuses. Often, such groups identify themselves using different terms, such as Roma people, Gypsy, Kalderash, Traveler, and others. The latter term is associated with "nomads" or "nomadic nation", as the Roma have historically not been considered a sedentary ethnic group. Research is often linked to a politicized debate on the Roma, which seeks to define in general what Roma is and why it is important to answer this question [27].

The term romaphobia seeks to describe the fear, inherent in racism against the Roma. In this case, it is quite similar to the term Islamophobia (it is true, that there is a lot of discussion about the use of the terms Islamophobia and Muslimophobia) [28]. Romaphobia can reflect the hostility and anxiety that manifests itself in many anti-Roma discourses and even actions against them. For 
example, the media play an important role in supporting romaphobia, as well as in shaping stereotypes in society. However, romaphobia is not just about prejudice, discrimination or a certain kind of antagonism in society. It is also related to racism [29]. This concept emphasizes ideologically based hostility towards certain minority groups, as in the case of the concept of Islamophobia or Muslimophobia [30].

The theoretical part is based on a constructivist approach to the Roma as a highly stereotyped minority in the Lithuanian media. Most studies on Roma analyze the political context and aspects of policy decisions. However, too little attention is paid to racial discrimination, human rights issues, public attitudes and negative attitudes towards this minority or media representation [31]. Political decisions are often disguised as ethnic, cultural differences or the "Clash of Civilizations" as described by [32]. However, it must be acknowledged, that the concept of Romaphobia is not universally accepted. On the contrary, it is considered, that such a concept is intended only to draw attention, as there are more acceptable terms, such as anti-Roma racism, anti-Gypsyism or antiziganism [29].

The social, economic or even political situation of the Roma is often used in the media to create an image of crime (crimes), poverty, education or exclusion in society. The aim is to convince readers that such negative characteristics are unique to people, belonging to this minority. Research shows that the target audience (i.e. readers) associates poverty with the "natural" characteristics of Roma rather than with structural problems with the government (e.g., failed government policies to integrate Roma) [33]. However, factors of exclusion and inequality should be taken into account in order to make broader generalizations about the situation of the Roma in the country. According to [7], Roma exclusion occurs in various areas of life. Examples include job search, education, housing, health and even human rights. Very severe forms of exclusion can also be mentioned, such as denial of citizenship [34] or deportation of Roma [8]. Most Roma in Europe experience various forms of exclusion. For example, education is an important area of exclusion in Lithuania. Compared to 2001, according to the data, in 2011 the share of people with secondary and higher education in the Roma group decreased (from $28 \%$ to $20 \%$ ). Roma education rates still differ significantly from the national average [35].

Studies have confirmed that Roma children experience ethnic and social segregation in many European Union countries [9]. This has long-term negative consequences. The exclusion of the Roma is also evident in the labor market. For example, in Lithuania in 2011 unemployment among Roma was $34 \%$ (national average - $11 \%$ [35]. Racial discrimination in employment is also noticeable in 2011-2013. The results of the survey on public attitudes show that approximately half of the Lithuanian population (42-48 \%) would not want to work in the same workplace with Roma people (ibid.) [35]. For these structural reasons, the Roma are "excluded", treated as "others", outside the majority of society. Roma people are seen and perceived as members of an outgroup or even as a burden on government [36]. This ultimately results in the Roma community being generally considered non-state. A statement from Amnesty International (2020) states that for this reason, Roma often experience various human rights violations, violence, harassment. Dignity may be taken away, ethnic or racial hatred may be incited, or racist statements by politicians may even become apparent [20].

\section{3. Theory of Social Constructivism}

The basic concept of constructing social reality is that individuals and groups interact in social systems and with time this creates concepts or representations of each other's actions. These concepts eventually become commonplace and form universally accepted roles that are assigned to actors in relationships with each other. When these roles become valid for other members of society, then mutual interactions are institutionalized. In this process of institutionalization, society has an important role. Therefore, it is said, that reality is socially constructed. In other words, knowledge constitutes certain meanings that are important to the functioning of any society. Reality is accessible to any member of society, and the very social construction of reality is a necessary condition for the vitality of society [37]. 
It is a generally accepted norm that people are already born with certain possibilities of cognition, but the vast majority of criteria or methods of knowledge are nonetheless constructed. [38] states that knowledge is created by humans in a process that is minimally constrained with the inputs from nature, but at the end of the knowledge production (p. 5-6). The author associates the origin of knowledge with the intellectual and cognitive processes present in each individual, but for some constructivists the "design" of knowledge is considered sociopolitical (therefore, in a sense social) and not solely or exclusively "internal", psychological or intellectual in nature [38].

Constructivists argue that cultures are not "real", but abstract, useful fictions. All concepts and theories are social constructs. All knowledge (including scientific) is historically and socially influenced and described as a "falsified" perception. However, social structures may change. The existence of a particular culture does not mean that it always remains static. Human interactions and social relationships are also constructed. [39, 40] states that the human world is not natural, but on the contrary, it is a machine, constructed by the actions of the participants themselves (p. 16-17). In other words, it is the work of the actors themselves. Even people's opinions, values, certain attitudes are formed by entire generations of people. Human identity is not natural and stable, but constructed, and sometimes even completely fictional. Therefore, social identity is related to interpretation and independent of empirical facts.

Reality of everyday life is pre-designed and classified according to certain patterns. It exists as a self-evident and obvious fact where values and worldview have a social motive [37]. Constructed reality always depends on the social basis and structures, required for its legitimacy. An individual can maintain his or her identity only in an environment that can validate it. For example, the Catholic faith can only be maintained through contact with the Catholic community, so identity is one of the essential elements of subjective reality [37].

\section{4. Media, Discourse, Stereotypes}

The media is "a mirror of events that, regardless of our preferences, distorts, corrects, filters, and selectively chooses what we know, see, and hear" [41, p. 13]. Thus, not only does the social environment affect the media, but the latter also has a similar effect on the social environment. The research model of mass communication [42] highlights the power and impact of the media on society, but also emphasizes the normative role of society in the media. The media carry out socialization, information, mobilization and, ultimately, opinion-forming of the public. In analyzing the media as a stereotype maker, it is important to know that journalists can create messages or communication [43, p. 45]. Often, they selectively choose what can be conveyed to the audience, based on the relevance of the message.

However, media communication is not seen as a fixed phenomenon that is understood by the entire audience, but as a constantly changing and evolving process. The received message is decoded differently in each society, because the audience, to which the message is sent, depends on social, economic, cultural, political circumstances [41]. Therefore, reading a media report is an active process, in which context, social status, and previous experience may lead to different decodings of meanings. Researchers studying media content often ignore this process, assuming that a dominant meaning will be passively accepted in an undifferentiated audience [44].

[45] stated that much of our knowledge does not come from our own personal experiences, but is created by the people around us. The media has a huge role to play in presenting the perceptions that make up our "agreed reality". People base their behavior on such perceptions by subconsciously abandoning "objective reality". In this context, social reality can be perceived as unverified information that is shared with those around you, who share the same information and ideas [46].

[47] states that mass communication studies assume that media has significant effects [47, p. 327]. The media actively identifies the frames of reference that readers or reviewers use to interpret and discuss public events. According to [48, p. 120] media can affect perception of historical events, based on their views and target audience. Information, presented in the media, is selective. This selection results from limited supervision and is often driven by financial motives. The media decides what stories to choose, highlight, interpret, and present to the audience. In this 
way, media controls people's attitudes or beliefs. [42, 49] emphasizes that since people have limited opportunities to follow important events directly, they have been dependent on the press to provide them with information. The main role of the media is to provide us with information, related to the "outside world", but reality is often hidden, and readers trust the "reality", portrayed by the media.

Every aspect of a text, presented in the media, is the result of a choice - the choice to use a particular concept to describe a person, action or process, the choice to use a particular sentence construction, the choice to include a particular fact or argument [50]. These facts do not exist in isolation, but relate to certain assumptions. If both the journalist and the majority of readers associate the Roma with the threat, news editors will try to show it in the headlines and present it using specific phrases. Minorities are often stenciled as security threats, and the actions of several individuals are attributed to the whole community. Information is selected and presented in such a way that the reader's interpretation is relevant to the prevailing view in society. Often, even minority-friendly newspapers do not have journalists or editors, who specialize in national minority issues or have some understanding of these communities [51]. Thus, in summary, the media can play a role in representing social reality and shaping stereotypes of certain groups, such as national, social and ethnic minorities.

\section{5. Opportunities for Roma to Shape Social Reality}

The opportunities of the Roma to construct social reality (and thus change the negative stereotypes) are limited. This has to do with their position in society. [52] defined social exclusion as a condition, in which individuals or communities are geographically part of that society, but feel unable to participate in the normal activities of citizens because of their understanding, conditions and institutions that limit or deny their participation. Individuals or communities may feel that society and institutional structures prevent them from participating in public life as citizens. It can be said, that in such a case the possibilities of constructing social reality are limited. In other words, social exclusion can be perceived as the limited opportunities of a certain section of society to participate in the political, social, cultural or economic life [53]. The minority community cannot express its position, eliminate the stereotypes that exist in society through the media. A minority does not have sufficient political, cultural, or economic capacity to exert any influence [54].

Roma have always been perceived as nomadic nations, who travel from one place to another and do not have their own state [55]. The most common stereotypes are related to education (Roma are considered uneducated), crime (thieves, drug traffickers), laziness (unwilling to work or study), marital status (number of children), disorder (living in remote places, not following hygiene norms), integration (Roma living in their own close communities or even hostile attitudes to other members wider society) and so on [56]. Negative perceptions of Roma also affect other areas of life, such as growing antipathy or fear of Roma. They feel excluded and discriminated, becoming victims of psychological violence (especially children in schools). The social stigma experienced is also related to the negative attitudes towards the Roma that are formed and maintained with the help of the media. As an example, one of the newspapers writes about the crime rate and states that the majority of detained people are Roma. In this way, the aim is to support and reinforce the stereotypes and myths that exist in society (one can also recall R. Barthes' insights about the power of myth) [57].

Roma stereotypes exist not only in the press, but also on television (criminals, murderers, etc.). The Roma people also face persecution, which is linked to the legal and political system. The brutal treatment of Roma by law enforcement authorities is observed, which is linked to the under-representation of Roma people [58]. Thus, the common experiences that unite nations are often conveyed through specific social interactions and the media. Minorities receive information about how people treat them. From the media (press, television, films), they receive inclusion / exclusion signals, directed at minority groups [59]. As a result, members of minority groups have a strong sense of solidarity that results from shared exclusion.

\section{6. Research Methods, Sources and Data Collection}

According to [60], content analysis refers to any systematic reduction of the flow of text (or other symbolic forms) to a standard set of statistically processed symbols that reflects the presence, 
intensity or quantity of certain socially relevant characteristics. According to [61], content analysis seeks to (1) identify the bias of media messages, which manifests itself in one way or another in shaping the images regarding certain groups in society, (2) to discover real-life reflections (or discover what is not in media texts), (3) to find out how the media constructs and supports myths in society.

In the social sciences, it is not only the text that is written, but also the actors, who create, transmit, interpret it, and the context that enables or limits it is important. News reports are an ideal source of data, from which we can learn about the social meanings and stereotypes, created through language and communication. In the language, used in the text, we can find clues that would promote a certain value orientation by representing or stereotypically depicting specific groups. Speeches by certain groups (politicians, religious leaders or oppressed groups) can penetrate the news discourse and become an acceptable part of the structure [62].

The analysis of the content of media articles was determined by the following factors:

1) the availability of the media as a data source;

2) the language, used in the media, can reflect society and culture itself;

3 ) the media (by presenting people and problems) can influence attitudes and opinions in society [63].

The study of the content analysis covers January 2019 - August 2020.

Two different online news websites in Lithuania have been selected in order to find out how Roma are presented in Lithuanian public discourse. The sources are selected, based on the following criteria:

1. Use of the keyword "Roma".

2. Daily number of visitors of websites.

3. Availability of accessing the articles.

3. 1. Search engine: Availability to use search engines to access articles on the websites using keywords or time intervals.

3. 2. Financial aspects: Availability to access articles on the websites with no extra charge.

Based on the criteria above, the following online daily news websites were selected: 15 min.lt (daily visitors according to the data of September 2020 are 469,559 visitors (12.32\%)) and Lrytas.lt (343,433 daily visitors (11.62\%)) [64].

After entering "Roma" keyword, 452 articles were found on the websites. The articles were checked again to ensure that only whose topic is on the Roma community were included in the study (for the selected period, i.e. January 2019 - August 2020). A total of 80 articles (40 from each news portal) were selected for the qualitative study, in which the main topic is related to Roma people.

\section{7. Research Ethics}

Qualitative research makes it difficult to maintain impartiality in data collection and analysis. In terms of Roma stereotypes, we already have some images, related to their behaviour or appearance. So, it would be unethical to say that our pre-defined ideas do not reflect how we interpret the results of the study. However, ethical principles are based on four main areas. As for the first principle of "harm of participants", this is not a problem of this study, as the identity of the actors, involved in the media discourse, is not revealed in the study. As "participants" are not identified, but only examined in the context of the article, other issues, related to "lack of consent", "invasion of privacy" and "deception", is also not a problem of this study [65].

To ensure the objectivity of the study, the author declares that there is no conflict of interest. Personal or financial relationships and personal beliefs were irrelevant while analysing data. The analysis of the data and the presentation of the information are in no way related to the author's ethical or other beliefs or belonging to a particular ethnic, social, religious or any other group.

\section{Result}

\section{1. Results of Qualitative Content Analysis}

The results of the qualitative content analysis are presented below. Information about Roma people is obtained from two different news portals (15min.lt and Lrytas.lt). The results are pre- 
sented on the basis of 3 different discourses that emerged during the research: security discourse, socio-economic discourse, integration discourse.

\section{2. Security Discourse}

While analysing the articles, selected for qualitative content analysis, it was noticed that in the articles of the 15min.lt news portal, there is a greater tendency to associate Roma with a certain threat or danger, more specifically to drug trafficking. An article titled "Tabor (a historical Roma camp in Vilnius) almost demolished, but drug trafficking does not stop: a man with powder was caught" [66] reports that a man, who was carrying drugs, was arrested in the Roma camp, which was being demolished in 2020. The article cites police officers and the head of the police commissariat. Similarly, another article, published on the news portal $15 \mathrm{~min}$.lt, tells about how Roma people "attacked" police officers. The article comes with a loud headline that uses a rhetorical exclamation and a negative connotation for the word "attacked" ("During a police operation at the camp, the Roma attacked the police: "Grass" is not a drug, it helps to relax even for children!"). The article is emphasizing that during the arrest of the offender, relatives (including minors) were very outraged by the actions of the officials, as they did not understand that these were prohibited drugs, for the possession of which a pre-trial investigation is being initiated [67].

Roma people are associated not only with drug trafficking, but also with other crimes, such as theft or murder. Another dominant image regarding the Roma in the $15 \mathrm{~min}$.lt discourse is also related to the rhetoric of negative connotation as Roma people are associated with crime. The article entitled "Police caught 2 women after a complicated investigation" reports a police investigation, in which two Roma women were accused of fraud and theft from elderly people across Lithuania. The article constantly emphasized the background of women, even several times (3), mentioning the term "Roma", "Roma nationalities": "Roma people are suspected of having travelled to various places in Lithuania to introduce themselves as employees of the State Social Insurance Fund or grid companies to enter inside those houses, belonging elderly people to loot and steal valuables. The women drew up a crime plan and distributed the tasks. They found vehicles to travel to crime scenes; also found a driver, who drove them all over Lithuania for a commission" [68]. The article also emphasized that women had a criminal record with other similar crimes.

However, analysing the Lrytas.lt discourse reveals more links between Roma and criminal activity. In the case of 15 min.lt, emphasis is placed on illegal drug trafficking, while on the discourse of Lrytas.lt news portal there is a greater concentration on such criminal offenses as murder. The article on Lrytas.lt is shared about the final verdict in the case of killing a 26-year-old girl. Three young Roma are on judgement for a heinous crime. The article also does not avoid the use of terms such as "the leader of a gypsy gang", "not only gypsies will hear the verdict", "biographies have been "rich" in their convictions since previous times", "hijacking cars and committing other crimes" [69]. Another article on the Lrytas.lt reported the murder of a 22-year-old in Vilnius while mentioning about the killer and also five other people including two Roma. It is told about a taxi driver's meeting with two young Roma. The article reports about a road rage event, in which a Roma driver and passenger pulled out an axe and threatened another driver. The word Roma is used in the article four times: "Roma youth", "Roma sitting next to the driver", "Roma passengers", "why Roma needed to travel at night" [70]. These examples can illustrate the process of creating stereotypes, as the latter is a consequence of building links, in which characteristics (i.e., crime) are attributed to a particular group (in this case, Roma people). In this way, with the influence of the media negative links are formed which are later supported and become rooted in the negative attitudes of society towards the Roma.

However, there is also an alternative discourse, in which some of the journalists' statements about the Roma are criticized. In the article it is criticized the journalist's TV show, which as emphasized allegedly "opened the wounds of the Roma". Some of the speeches were described as unethical, but the journalist defended that the nature of the show was satirical. In the TV show, well-known TV host talks about a "gypsy" tabor, or as he is emphasizing maybe "Roma" tabor, an address, often mentioned in taxi legends and by drug addicts. After decades of fighting between locals, the municipality and the tabor residents, the tabor will finally be demolished. Hu- 
man rights defenders particularly criticise the parallels of words, used from Hitler's book "Mein Kampf" whereas, it was used the paraphrase of the Nazi vocabulary - "solve the Roma problem" by physically destroying them. Also it was proposed to take children of Roma people from them. It was mentioned, that according to a statistic, in the Czech Republic $86 \%$ of population would not want to live with a Roma neighbour while in Lithuania this number was 66 percent (According to 2015 data) [71]. Thus, although such unethical comments of the journalists regarding Roma have been criticized, it must be noted, that an alternative, dialogue-promoting approach is also lacking especially in the Lrytas.lt portal.

\section{3. Socio-economic Discourse}

The analysis of socio-economic discourse highlights two main problems: integration into the labour market and education. The first recognises that integration into the labour market has been an ongoing problem for many years. In 2020, a new almost four-year programme for Roma integration was approved and presented (the old one was to address the Roma Tabor problem by 2019). The article states that subsidies are provided for businesses employing people of Roma origin. According to the council member, the attitude of Vilnius residents towards the Roma is also changing, stereotypes are being reduced and Roma social business is increasingly being introduced, e. g. cafes, restaurants and other [72]. However, no specific evidence or arguments are provided to support the changing attitudes of the urban population towards the Roma, therefore, such information is not objective.

A representative of the Office for Equal Opportunities Ombudsman presents the situation concerning discrimination at work. In fact, discrimination against the Roma is such a "norm" of life that it is no longer considered as discrimination [73]. This is also evidenced by the above mentioned journalist's TV show about the Roma, which said that one of the characteristics of the Roma was laziness: all "gypsies" were allergic to work and that their children did not want to study [74]. Similarly, the discourse of the Lrytas.lt news portal emphasizes joblessness, thefts and illegal trade. One interview reveals that although most Roma have been evicted from the tabor, drug trafficking is still on, with even use of children. Homeless drug addicts live in the very center of the capital, under the windows of unsuspecting families [75]. It is stated, that officials do not have the means to combat drug trafficking because of gaps in the legal system. It is also discussed why Roma citizens do not pay fines. According to the article, if a person does not have any property and work (it is stated, that "Roma people are just like that"), bailiffs have no means of punishing criminals or holding them accountable for their actions. Another article appearing on Lrytas.lt states that Roma women often admit that they sell cigarettes as they earn money for food, supporting children or family [76].

However, the qualitative analysis of the content shows that the "positive" discourse is mostly observed while discussing about employment of Roma people (in most cases, these are already well-known Roma people in society in entertainment business). For example, both $15 \mathrm{~min}$.lt and Lrytas.lt published articles regarding the first Roma restaurant in Lithuania, founded by a famous singer, sharing moments of the opening event, in which other public figures also took part [77]. From this point, an attempt is made to change public attitudes. The main actors in the discourse say that Roma, especially young people are willing to work, ready to be an exemplary face of their community, they aim to break down stereotypes, spread about Roma people in society. They are young, hardworking and they are proud to be Roma [78]. There are also cases, where prominent Roma figures express resentment about slander language against Roma (for example, they were raising their objections regarding a book that tells about Roma life in a negative way) [79].

Another emerging stereotype in the analysis of socio-economic discourse is that Roma are portrayed as uneducated, often unable to read or write. The media creates the image that Roma children are unmotivated to learn and do not have the capacity to do so by referring their supposedly "natural" laziness. For example, a video on the 15 min.lt portal shows a situation of "healthy" Roma children, which study in schools for children with special needs, because here they can get more economical benefits, provided by the government. A journalist investigation has revealed that parents of Roma children do not care that if their child will be recognized as having a mental disorder or not. No disabilities were identified for Roma children during the inspection of the special 
commission. According to the journalist, this happened due to the value principle that education is irrelevant to Roma children, therefore in schools for children with mental and intellectual disabilities at least they will learn to read and write [80]. In this way, Roma people are negatively portrayed as both being uneducated and that they are trying to exploit the social security system as much as they can. Meanwhile, on the Lrytas.lt website, during the period of analysis, no articles, whose main topic would be about Roma education or upbringing, were found.

One more negative image of the Roma is being seen around the issue of housing, which is discussed in more detail in the analysis of the integration discourse. The main subject of discussion is a historical Roma tabor in Vilnius, which has been built illegally. According to the representatives of the municipality, it was offered for the Roma community to move to social housing, which is provided by the municipality, but the Roma people say they have no place to move, and the so-called promises have not been fulfilled. There is outrage that "people first evicted, then they look for an alternative to accommodate them. Or not looking at all" (the chairman of the Lithuanian Roma Community and the head of the Roma Community Center spoke at the committee meeting) [81]. In addition, it is added that renting a house for Roma families is certainly not easy, because not everyone wants such tenants. Meanwhile, another news portal presents a story about social housing, provided to a young Roma family, where drugs have been found. The man, who has previously lived in a tabor, later moved to social housing for the municipality, and is well known to the police because he is convicted of theft not only in Lithuania, but also in the United Kingdom [82]. Thus, by reading these articles, readers may develop the image that social housing is provided to criminals (and/or former tabor residents), who could continue their illegal activities and even benefit from social security supports such as social housing, etc.

In summary, such negative portrayals of the Roma community in the socio-economic context affect many areas of life: growing antipathy, negative attitudes towards the Roma (for example, exclusion in the labour market or education system). It is assumed, that members of the Roma community, especially children, may experience problems of integration in society, even they might become victims of psychological violence, social stigma, as Roma people are portrayed as a marginalized part of society in media discourse.

\section{4. Integration Discourse}

The qualitative analysis of the content shows that the discourse of Roma integration in Lithuania is emerging. Most of the discussions, surrounding the Roma community, are on the historical Roma tabor in Vilnius. One article quotes the Vilnius mayor's statement about the "last days", left for the demolition of the tabor. According to the mayor, it was "a place of disorder, broken destinies and systematic poverty" [83]. Although the program for the integration of the Roma into society is being implemented (providing assistance and facilities for families wishing to leave the tabor), it is known that the biggest problem is the lack of an effective drug use reduction program. The mayor of the capital says it depends on the national government: "There is no any program that works properly. That is why we have those poor people, for whom the camp was the center of attraction". And not all Roma people, who have moved to different places, may have given up their old habits, but these problems become easier to solve than when they all live together in one place. $<\ldots>$ Even the tabor disappears, the problems remain, because neither the use nor the trade in illegal drugs have disappeared. There is still a long way to go to solve this problem..." [83]. In another article, also referring to the "fate" of the tabor, the Roma people are associated with filth and disorder. It is said, that the Roma had to leave behind the tabor clean. However, the reality is different, as mountains of waste remain and evidence of drug dependence can be found on the site of former houses [84]. Although statistics on funding for the Roma integration program are provided, the publication does not provide specific solutions or measures to achieve Roma integration in society.

Roma people are represented as having values opposite to those of the local population, often even with "incompatible" values or a "different" way of life. This is evident in the discourse of the news portal Lrytas.lt about the Roma community. In an article, appeared on Lrytas.lt, although the main topic is the destruction of the above-mentioned tabor, the drug trafficking was constantly emphasized, as drug traffickers continue to "travel to work" here every day. The head of the rel- 
evant police department is also sharing his comments, saying the problem of drug trafficking did not disappeared, although the scale has decreased (three or four years ago, 40 people on the average were found, who died of drug overdoses) [85]. One video tells the story of a campaign, held at a Roma tabor to fight against drugs. The Roma people in the video, who use uncensored words, were opposing the campaign. Moreover, the video also showed the daily life in a Roma tabor, such as clutter, filth and poor living conditions [86]. Another article presents a video, sharing people stories after demolition of the Roma tabor. Former residents of the tabor were stating that they had no place to live, one of them saying that he would live in a tent, another telling about his life story of selling drugs and staying in prison for 3 years. Officials were saying that after demolition, the drug trafficking had gone nowhere as people had moved to the city and also there had not been a single dwelling, where drugs had not been found [87]. The analysis represents the formation of a negative image regarding Roma people, claiming that they have a different way of life and the "reluctance" to integrate into society. The reader may get the impression that such people are not only unwilling, but also unable to integrate because they are inherently different or hostile to the dominant society. Neither the discourse of $15 \mathrm{~min}$.lt nor Lrytas.lt news portals represents specific ways to solve the problems of Roma integration in society.

However, the situation of Roma and their integration into society in Lithuania has been mentioned positively in reports and strategy documents. For example, a report, released by the European Union, highlights the progress, made by Lithuania in the Roma integration process. According to the report, the greatest progress, made by Lithuania, was in the field of Roma education by the establishment of the educational network, and the report also notes positively the solution to the problem of the Kirtimai settlement in 2017 and progress in protecting Roma culture and history [88]. Another story, which was published by both media portals, shares the experience (interview) of a Roma woman, who stated that "after experiencing so much racism and injustice, I should consider Lithuanians as my enemies" [89]. She says that she could not rent commercial spaces to start a business, and that she was fired once from an insurance company that she was working because of her Roma background, whereas there are a number of stereotypes about Roma in society and in the labor market. Roma people often face difficulties in finding a job due to lack of education, also Roma children experience exclusion in the education system [90]. In addition, the number of cases of hate crimes and incitement to hatred in Lithuania may be much higher than the numbers, released in official statistics. However, the Roma community is not the only a target of racism or discrimination. Persons of other races in Lithuania feel disliked and strangers as well. One study assesses the state of vulnerability of Jewish, Roma and Muslim communities, as well as LGBTI people living in Lithuania. All communities surveyed lack adequate support and representation [91]. Moreover, not only negative comments in the media and on social networks, but also public statements by politicians that contribute to incitement of hatred in society can be considered an insult.

Although the media discourse sometimes seeks to draw attention to tolerance and solidarity with people of other nations, including Roma, such media content is not enough to draw attention to the problems, faced by Roma. Negative discourse dominates, therefore few articles (aimed at highlighting problems of integration into society, especially in the context of stereotyping and marginalization) are not enough to change negative media discourse and shape favorable societal attitudes towards Roma.

\section{Conclusions}

The term romaphobia is intended to describe the fear, inherent in racism against the Roma. In this case, it is quite similar to the concept of Islamophobia. Romaphobia can reflect the hostility and suspicion that is evident in many anti-Roma discourses. Media plays an important role in supporting romaphobia, as well as in shaping stereotypes in society. However, it must be acknowledged, that the concept of Romaphobia is not universally accepted. On the contrary, it is considered that such a concept is only intended to draw attention, as there are other terms such as anti-Roma racism, Antigypsyism, Antiziganism or anti-Romani sentiment.

The minority rights approach is clearly insufficient to promote the social inclusion of the Roma. Similarly, policies, targeting the Roma without effective integration into the education sys- 
tem, employment promotion and equal social rights can be considered ineffective. It is no less important to recognize the ethnic identity and historical grievances of the Roma. However, given the prejudice and discrimination that Roma face in various areas of life, Roma should strive for (legal, political and social) equality and opportunities to identify themselves as Roma. As long as the majority of society stigmatizes the Roma, democratic equality and recognition of minority rights will lose their meaning. For this reason, the article discusses the opportunities of the Roma nation to represent itself and thus construct social reality.

The results of the qualitative content analysis show that in the case of the $15 \mathrm{~min}$.lt portal, there is a tendency to associate the Roma with a certain threat or danger (in the context of the security discourse). One of the most common criminal stereotypes is drug trafficking or theft. Meanwhile, the discourse of news portal Lrytas.lt has a greater concentration on criminal crimes as murders. The articles in those portals do not avoid the use of terms such as "Roma", "gypsies", "gypsy gang", "biographies rich in convictions", "horrific crimes", "well known to the police", "convicted of theft" and others. It is assumed, that this creates a negative value orientation of readers towards the Roma community. Negative behaviours (i.e., crime) are attributed to the whole group rather than to the person, who committed the crime. In this way, the negative associations, created and maintained with the help of the media, later become rooted in the negative attitude of society towards the Roma.

The analysis of socio-economic discourse highlights three main problems (in both $15 \mathrm{~min} . l \mathrm{lt}$ and Lrytas.lt) - integration into the labour market, the issue of accommodation and education. The first recognises that integration into the labour market has been an ongoing problem for many years. Paradoxically, most of the "positive" discourse is also observed in relation to the activities and employment of Roma people (in most cases, Roma people, who are well-known in society and are associated with the entertainment business).

The analysis of the discourse on Roma integration in Lithuania reveals that the most common topic is the Roma tabor, located on the outskirts of the capital. As a result of the illegal drug trade, Roma people are represented as having opposite values than the local population, often even "incompatible" values or a "different" way of life. Main actors, involved in both 15 min.lt and in Lrytas.lt are police officers, chief police officers, representatives of the municipality (e.g. mayor, councillors), who provide information and comment on drug trafficking, eviction of Roma from the tabor, social housing or integration into the labour market. It is noted, that $15 \mathrm{~min}$.lt gives a space for the opinions, expressed by Roma representatives (such as the comments and opinions by the President of the Lithuanian Roma Community and the Head of the Roma Society Centre on the eviction of Roma, social housing and demolition of the tabor). Meanwhile the discourse of Lrytas. $l t$ is dominated by editorial articles, where the situation is evaluated by journalists themselves with some occasional cases, where the opinions of politicians or other public figures are also presented. The language, used in news articles, aims to create a dichotomy between "we" and "others" in shaping the relevant attitudes of society.

\section{References}

[1] Statistikos departamentas (2012). Lietuvos Respublikos 2011 metų gyventojų ir būstų surašymo rezultatai. Vilnius: Lietuvos statistikos departamentas.

[2] Communication from the Commission to the Council, the European Parliament, the European Economic and Social Committee and the Committee of the Regions The Social and Economic Integration of the Roma in Europe /* COM/2010/0133 final */ (2010). European Commission. Available at: https://eur-lex.europa.eu/legal-content/EN/TXT/?uri=celex \%3A52010DC0133

[3] Communication from the Commission to the European Parliament, the Council, the European Economic and Social Committee and the Committee of the Regions An EU Framework for National Roma Integration Strategies up to 2020/* COM/2011/0173 final */ (2011). European Commission. Available at: https://eur-lex.europa.eu/legal-content/en/ALL/?uri=CELEX \%3A52011DC0173

[4] Reikminių tyrimų projektas „Prieglobstị gavusių užsieniečių integracijos politikos ịgyvendinimo vertinimas ir integracijos procesų stebėsena. Projekto ataskaita. Projektą finansavo Lietuvos mokslo taryba (sutarties Nr. REP2/2016) (2016-2017). Lietuvos socialinių tyrimų centro Etninių tyrimų institutas, 1-195.

[5] Visuomenès nuostatų apklausos rezultatai: 2019 m. kovo 25 - balandžio 10 d. (2019). Lietuvos socialinių tyrimų centro Etninių tyrimų institutas, 1-12. 
[6] A. Zuokas 2014 m. nori pradèti „spartų romų iškeldinimą iš taboro“ (2012). Delfi.lt. Available at: https://www.delfi.lt/news/ daily/lithuania/azuokas-2014-m-nori-pradeti-spartu-romu-iskeldinima-is-taboro.d?id=55437701 Last accessed: 20.09.2020

[7] Kertesi, G., Kézdi, G. (2006). Expected Long-Term Budgetary Benefits to Roma Education in Hungary. Budapest Working Papers on the Labour Market, No. BWP - 2006/5. Hungarian Academy of Sciences, Institute of Economics. Budapest, 1-59.

[8] McGarry, A., Drake, H. (2013). The Politicization of Roma as an Ethnic "Other": Security Discourse in France and the Politics of Belonging. The Discourses and Politics of Migration in Europe. New York: Palgrave, 73-91. doi: http://doi.org/10.1057/9781137310903_5

[9] Messing, V. (2017). Differentiation in the Making: Consequences of School Segregation of Roma in the Czech Republic, Hungary, and Slovakia. European Education, 49 (1), 89-103. doi: http://doi.org/10.1080/10564934.2017.1280336

[10] Van Baar, H. (2011). Europe's Romaphobia: Problematization, Securitization, Nomadization. Environment and Planning D: Society and Space, 29 (2), 203-212. doi: http://doi.org/10.1068/d2902ed1

[11] Tremlett, A. (2013). "Here are the Gypsies!" The importance of self-representations and how to question prominent images of Gypsy minorities. Ethnic and Racial Studies, 36 (11), 1706-1725. doi: http://doi.org/10.1080/01419870.2012.669487

[12] Vermeersch, P. (2012). Reframing the Roma: EU Initiatives and the Politics of Reinterpretation. Journal of Ethnic and Migration Studies, 38 (8), 1195-1212. doi: http://doi.org/10.1080/1369183x.2012.689175

[13] Tremlett, A., Messing, V., Kóczé, A. (2017). Romaphobia and the media: mechanisms of power and the politics of representations. Identities, 24 (6), 641-649. doi: http://doi.org/10.1080/1070289x.2017.1380270

[14] Stauber, R., Vago, R. (2007). The Roma: A Minority in Europe: Historical, Political and Social Perspectives. Budapest: Central European University Press, 206.

[15] Kenrick, D. (1971). The World Romani Congress - April 1971. Journal of the Gypsy Lore Society, 50 (3-4), 101-108.

[16] Tautinės bendrijos. Tautinių mažumų organizacijos. Romai (2017). Tautinių mažumų departamentas prie Lietuvos Respublikos Vyriausybės. Available at: https://tmde.lrv.lt/lt/tautines-bendrijos/tautiniu-mazumu-organizacijos/romai Last accessed: 20.09.2020

[17] McGarry, A. (2014). Roma as a political identity: Exploring representations of Roma in Europe. Ethnicities, 14 (6), $756-774$. doi: http://doi.org/10.1177/1468796814542182

[18] Willems, W. (1998). In Search of the True Gypsy: From Enlightenment to Final Solution. Abingdon: Routledge, 380. doi: http:// doi.org/10.4324/9781315810225

[19] Acton, T., Ryder, A. (2012). Recognising Gypsy, Roma and Traveller History and Culture. Gypsies and Travellers: Empowerment and Inclusion in British Society. Bristol: Polity Press, 135-149. doi: http://doi.org/10.1332/policypress/9781847428950.003.0008

[20] Italy: Violations of Roma, Refugee and Migrants' Rights Continue, Accompanied by the Criminalization of Rescue NGOs (2020). Amnesty International, 1-2. Available at: https://www.amnesty.org/download/Documents/EUR3019642020ENGLISH.PDF Last accessed: 21.09.2020

[21] McGarry, A., Drake, H. (2013). The Politicization of Roma as an Ethnic Other: Security Discourse in France and the Politics of Belonging. The Politics and Discourses of Migration in Europe. New York: Palgrave Macmillan, 73-91. doi: http://doi.org/ 10.1057/9781137310903_5

[22] Van Baar, H. (2011). The European Roma: Minority Representation, Memory and the Limits of Transnational Governmentality. University of Amsterdam, 400.

[23] Sigona, N. (2014). Campzenship: reimagining the camp as a social and political space. Citizenship Studies, 19 (1), 1-15. doi: http://doi.org/10.1080/13621025.2014.937643

[24] Bernáth, G., Messing, V. (2013). Pushed to the Edge. Research Report on the Representation of Roma Communities in the Hungarian Majority Media, 2011. Budapest: CPS Working Paper Series 2013/1, 51. Available at: https://cps.ceu.edu/publications/ working-papers/pushed-to-the-edge Last accessed: 21.09.2020

[25] Surdu, M. (2016). Expert Frames. Scientific and Policy Practices of Roma Classification. Budapest: CEU Press, 276.

[26] Turner, L. (2019). The Politics of Labeling Refugee Men as "Vulnerable." Social Politics: International Studies in Gender, State \& Society. doi: http://doi.org/10.1093/sp/jxz033

[27] Tremlett, A. (2009). Bringing hybridity to heterogeneity in Romani Studies. Romani Studies, 19 (2), 147-168. doi: http:// doi.org/10.3828/rs.2009.8

[28] Sutkutė, R. (2019). Islamofobija, musulmonų reprezentacija ir stereotipai vakaruose po 9/11 ịvykių. Jaunųjų mokslininkų darbai, 49 (2), 36-51. doi: http://doi.org/10.21277/jmd.v49i2.234

[29] Tremlett, A., Messing, V., Kóczé, A. (2017). Romaphobia and the media: mechanisms of power and the politics of representations. Identities, 24 (6), 641-649. doi: http://doi.org/10.1080/1070289x.2017.1380270

[30] Sutkute, R. (2019). Media, stereotypes and muslim representation: world after jyllands-posten muhammad cartoons controversy. EUREKA: Social and Humanities, 6, 59-72. doi: http://doi.org/10.21303/2504-5571.2019.001054

[31] Stewart, M. (2013). Roma and Gypsy "Ethnicity" as a Subject of Anthropological Inquiry. Annual Review of Anthropology, 42 (1), 415-432. doi: http://doi.org/10.1146/annurev-anthro-092010-153348 
[32] Huntington, S. P. (2011). The Clash of Civilizations and the Remaking of World Order. New York: Simon \& Schuster, 368.

[33] Janky, B., Janky, B., Bakó, B., Szilágyi, P., Bognár, A. (2014). Stigmatising the Poor without Negative Images: Images of Extreme Poverty and the Formation of Welfare Attitudes. Sociological Research Online, 19 (3), 246-255. doi: http:// doi.org/10.5153/sro.3447

[34] O’Nions, H. (2015). How Citizenship Laws Leave the Roma in Europe's Hinterland. The Human Right to Citizenship: A Slippery Concept. Pennsylvania: University of Pennsylvania Press, 145-158.

[35] Dẻl romų integracijos ị Lietuvos visuomenę 2015-2020 metų veiksmų plano patvirtinimo. İsakymas, Įsakymą prièmė Lietuvos Respublikos kultūros ministerija. Nr. IৃV-48. e-seimas.lrs.lt, TAR, 2015-01-30, Nr. 1320 (2015). Lietuvos Respublikos Seimas. Available at: https:/e-seimas.lrs.lt/portal/legalAct/lt/TAD/6caa6010a8cb11e4a854e1c2026e476c/rpBnEixRmj?jfwid=-k1k4j8slf Last accessed: 18.09.2020

[36] Schneeweis, A., Foss, K. A. (2017). "Gypsies, Tramps \& Thieves": Examining Representations of Roma Culture in 70 Years of American Television. Journalism \& Mass Communication Quarterly, 94 (4), 1146-1171. doi: http:// doi.org/10.1177/1077699016682723

[37] Berger, P. L., Luckmann, T. (1999). Socialinis tikrovès konstravimas. Vilnius: Pradai, 263.

[38] Phillips, D. C. (1995). The Good, the Bad, and the Ugly: the Many Faces of Constructivism. Educational Researcher, 24 (7), 5-12. doi: http://doi.org/10.3102/0013189x024007005

[39] Bader, V. (2001). Culture and Identity: Contesting Constructivism. Ethnicities, 1 (2), 251-273. doi: http://doi.org/10.1177/1468 79680100100206

[40] Kratochwil, F. (2001). Constructivism as an Approach to Interdisciplinary Study. Constructing International Relations: The Next Generation. Armonk/London: M. E. Sharpe, 13-35.

[41] Uznienè, R. (2009). Medijinis ugdymas: švietimas, lavinimas ir mokymas apie žiniasklaidą. Klaipėda: Klaipédos universiteto leidykla, 112.

[42] Lowery, S. A., DeFleur, M. L. (1995). Milestones in Mass Communication Research Media effects. White Plains: Longman, 432.

[43] Fiske, S. T. (1998). Stereotyping, Prejudice and Discrimination. The Handbook of Social Psychology. New York: McGraw-Hill, 357-411.

[44] Gamson, W. A., Croteau, D., Hoynes, W., Sasson, T. (1992). Media Images and the Social Construction of Reality. Annual Review of Sociology, 18 (1), 373-393. doi: http://doi.org/10.1146/annurev.so.18.080192.002105

[45] Boulding, K. E. (1964). The Meaning of the Twentieth Century: The Great Transition. New York: Harper and Row.

[46] Gorham, B. W. (1999). Stereotypes in the Media: So What? Howard Journal of Communications, 10 (4), 229-247. doi: http:// doi.org/10.1080/106461799246735

[47] McQuail, D. (1994). Mass Communication Theory: An Introduction. Thousand Oaks: Sage.

[48] Neuman R. W., Just M. R., Crigler A. N., (1992). Common Knowledge. News and the Construction of Political Meaning. Chicago: University of Chicago Press, 190.

[49] Lippmann W. (1922). Public Opinion. Oxford: Harcourt, Brace, 427.

[50] Richardson, J. E. (2007). Analysing Newspapers: an Approach from Critical Discourse Analysis. Basingstoke: Palgrave Macmillan, 268. doi: http://doi.org/10.1007/978-0-230-20968-8

[51] Engineer, A. A. (1999). Media and Minorities: Exclusions, Distortions and Stereotypes. Economic and Political Weekly, 34 (31), 2132-2133.

[52] Burchardt, T., Le Grand, J., Piachaud, D. (1999). Social Exclusion in Britain 1991-1995. Social Policy \& Administration, 33 (3), 227-244. doi: http://doi.org/10.1111/1467-9515.00148

[53] Yasmeen, S. (2008). Understanding Muslim Identities: from Perceived Relative Exclusion to Inclusion. Report. Centre for Muslim States and Societies, University of Western Australia, Crawley WA 6009, 89. Available at: http://www.law.uwa.edu.au/_data/ assets/pdf_file/0010/1138582/Understanding_Muslim_Identities.pdf Last accessed: 25.09.2020

[54] Magid, M., Khan, H. (2011). Muslim-Majority and Muslim-Minority Communities in a Global Context. Saban Center at Brookings.The Brookings Project on U.S. Relations with the Islamic World, U.S.-Islamic World Forum Papers, 14. Available at: http://www.brookings.edu/research/papers/2011/08/muslim-communities-magid-khan Last accessed: 19.09.2020

[55] Cheal, Y. (2012). Beyond the Stereotypes: a Review of Gypsies, Roma, Travellers and the Arts in Wales. Report of the arts council in Wales. Cardiff, 96. Available at: http://romaniarts.co.uk/wp-content/uploads/2012/12/Beyond-the-Stereotypes.pdf Last accessed: 25.09.2020

[56] Maučec, G. (2013). Identifying and Changing Stereotypes between Roman and Non-Roma: from Theory to Practice. Innovative Isues and Approaches in Social Sciences, 6 (3), 181-202. doi: http://doi.org/10.12959/issn.1855-0541.iiass-2013-no3-art10

[57] Barthes, R. (1972). Mythologies. New York: Hill and Wang, 158. 
[58] Beaudoin, J. (2015). Exploring the Contemporary Relevance of "Gypsy" Stereotypes in the Buffyverse. The Journal of Popular Culture, 48 (2), 313-327. doi: http://doi.org/10.1111/jpcu.12259

[59] Giddens, A. (2005). Sociologija. Kaunas: Poligrafija ir informatika.

[60] Shapiro, G., Markoff, J. A.; Roberts, C. W. (Ed.) (1997). Matter of Definition. Text Analysis for the Social Sciences: Methods for Drawing Statistical Inferences from Texts and Transcripts. Mahwah: Lawrence Erlbaum Associates, 9-32. doi: http:// doi.org/10.4324/9781003064060-1

[61] Balčytienè, A. (2000). Žiniasklaidos tekstai. Darbai ir dienos, 24, 109-120.

[62] Bell, A. (1991). The Language of news media. Wiley-Blackwell, 296.

[63] Devereux, E. (2007). Media Studies: Key Issues and Debates. London: Sage Publications, 392.

[64] Rugsėjo ménesio statistiniai duomenys (2020). Gemius Baltic. Available at: https://rating.gemius.com/lt/tree/59 Last accessed: 21.09.2020

[65] Diener, E., Crandall, R. (1978). Ethics in Social and Behavioral Research. Chicago: University of Chicago Press, 276.

[66] Taboras beveik nugriautas, bet narkotikų prekyba nestoja: ịkliuvo vyras su milteliais (2020). 15min.lt. Available at: https:// www.15min.lt/naujiena/aktualu/nusikaltimaiirnelaimes/taboras-beveik-nugriautas-bet-narkotiku-prekyba-nestoja-ikliuvo-vyras-su-milteliais-59-1315698 Last accessed: 24.09.2020

[67] Per kratą tabore romai užsipuolè policiją: „žolë“ ne narkotikas, padedanti atsipalaiduoti net vaikams! (2019). 15min.lt. Available at: https://www.15min.lt/naujiena/aktualu/nusikaltimaiirnelaimes/per-krata-tabore-romai-uzsipuole-policija-zole-ne-narkotikas-padedanti-atsipalaiduoti-net-vaikams-59-1228622 Last accessed: 23.09.2020

[68] Po sudettingo tyrimo policija sučiupo 2 moteris: iš senjorų pinigus viliojo visoje Lietuvoje (2020). 15min.lt. Available at: https:// www.15min.lt/naujiena/aktualu/nusikaltimaiirnelaimes/po-sudetingo-tyrimo-policija-suciupo-2-moteris-is-senjoru-pinigus-viliojo-visoje-lietuvoje-59-1321274 Last accessed: 23.09.2020

[69] Trainys, V. (2020). Paskutinis Ievos Strazdauskaitės žudikų gaujos žodis: vadeiva vos neapsiverkè. Lrytas.lt. Available at: https://www.lrytas.lt/lietuvosdiena/kriminalai/2020/02/21/news/kraupios-egzekucijos-byloje-baigiamieji-zingsniai-i-strazdauskaites-zudikai-taria-paskutini-zodi-13734622/ Last accessed: 24.09.2020

[70] Kuznecovaite, A. (2020). Kraupus jauno vaikino nužudymas Vilniaus r.: ịtarimai pareikšti šešiems asmenims. Lrytas.lt. Available at: https://www.lrytas.lt/lietuvosdiena/kriminalai/2020/07/27/news/kraupus-jauno-vaikino-nuzudymas-vilniaus-r-du-itariamieji-paleisti-i-laisve-vienam-ju-skirtas-suemimas-15756617/ Last accessed: 25.09.2020

[71] Meškinytè, A. (2020). Aštriai sukritikuota Andriaus Tapino laida atvėrè romų žaizdas: kaltina neetiškumu, žurnalistas ginasi - tai satyra. 15min.lt. Available at: https:/www.15min.lt/vardai/naujiena/lietuva/astriai-sukritikuota-andriaus-tapino-laida-atvere-romu-zaizdas-kaltina-neetiskumu-zurnalistas-ginasi-tai-satyra-1050-1322962? Last accessed: 26.09.2020

[72] Jačauskas, I. (2020). Vilniaus romų integracijos programoje - parama darbdaviams, specialistai mokyklose. 15min.lt. Available at: https://www.15min.lt/verslas/naujiena/karjera/vilniaus-romu-integracijos-programoje-parama-darbdaviams-specialistai-mokyklose-666-1366716 Last accessed: 24.09.2020

[73] Diskriminacija darbe: skundų mažai, bet situacija kebli (2020). 15min.lt. Available at: https://www.15min.lt/naujiena/aktualu/ lietuva/diskriminacija-darbe-skundu-mazai-bet-situacija-kebli-56-1260968 Last accessed: 25.09.2020

[74] Vilniaus taboras ir medžioklè lankais || Laikykitès ten su Andriumi Tapinu || S04E32 (2020). 15min.lt. Available at: https:// www.15min.lt/video/vilniaus-taboras-ir-medziokle-lankais-laikykites-ten-su-andriumi-tapinu-s04e32-181672 Last accessed: 25.09.2020

[75] Bauraitè, R. (2019). Atskleidè nepagražintą tikrovę: Vilniaus viduryje vyksta kraupūs dalykai. Lrytas.lt. Available at: https:// www.lrytas.1t/gyvenimo-budas/likimai/2019/03/04/news/atskleide-nepagrazinta-tikrove-vilniaus-viduryje-vyksta-kraupus-dalykai-9451623/; Last accessed: 25.09.2020

[76] Činkienè, J. (2020). Be baimès ir prieš kameras - Jonavos turguje knibžda romų nelegali prekyba cigaretemis. Lrytas.lt. Available at: https:/www.lrytas.lt/lietuvosdiena/kriminalai/2012/06/11/news/be-baimes-ir-pries-kameras---jonavos-turguje-knibzda-romu-nelegali-prekyba-cigaretemis-5272452/ Last accessed: 24.09.2020

[77] İ Ištvano Kviko romų restorano atidarymą plūdo seniai matyta visa Lietuvos grietinèlè (2020). Lrytas.lt. Available at: https:// www.lrytas.lt/zmones/veidai-ir-vardai/2020/07/01/news/i-istvano-kviko-romu-restorano-atidaryma-pludo-seniai-matyta-visa-lietuvos-grietinele-15469675/ Last accessed: 26.09.2020

[78] Ištvanas Kvikas Vilniuje atidare pirmajị romų restoraną: renginio nepraleido ir žinomi žmonės (2020). 15min.lt. Available at: https://www.15min.lt/vardai/naujiena/lietuva/istvanas-kvikas-vilniuje-atidare-pirmaji-romu-restorana-renginio-nepraleido-irzinomi-zmones-1050-1341458 Last accessed: 27.09.2020

[79] Vienuolès ir signataro žmonos knygoje - šmeižtas apie žinomus Lietuvos romus? Pasipiktino ir Radži (2020). 15min.lt. Available at: https://www.15min.lt/vardai/naujiena/lietuva/vienuoles-ir-signataro-zmonos-knygoje-smeiztas-apie-zinomus-lietuvos-romus-pasipiktino-ir-radzi-1050-1275520 Last accessed: 27.09.2020 
[80] Švietimo sistemos užribis: visiškai sveiki romų vaikai auklëjami internatuose su elgesio ir psichikos sutrikimų turinčiais vaikais (2020). 15min.lt. Available at: https://www.15min.lt/naujiena/aktualu/lietuva/svietimo-sistemos-uzribis-visiskai-sveiki-romu-vaikai-auklejami-internatuose-su-elgesio-ir-psichikos-sutrikimu-turinciais-vaikais-56-362752 Last accessed: 28.09.2020

[81] Grigaliūnaitè, V. (2019). Vilniaus romų bendruomenè ieško užtarejjų Seime - prašo negriauti taboro namų. 15min.lt. Available at: https://www.15min.lt/naujiena/aktualu/lietuva/vilniaus-romu-bendruomene-iesko-uztareju-seime-praso-negriauti-taboro-namu-56-1122074 Last accessed: 29.09.2020

[82] Kuizinaite, M. (2019). Prabangiausio socialinio būsto Lietuvoje gyventojams savivaldybė turi naujienų. Lrytas.lt. Available at: https:/www.lrytas.lt/lietuvosdiena/kriminalai/2019/08/29/news/pabegeliams-is-taboro-savivaldybe-turi-naujienu-kaltas-prabangus-socialinis-bustas-11626604/ Last accessed: 30.09.2020

[83] Šimašius, R. (2020). Remigijus Šimašius: Atsisveikinimas su taboru, kuris sugriautas be buldozerių. 15min.lt. Availg able at: https://www.15min.lt/naujiena/aktualu/nuomones/remigijus-simasius-atsisveikinimas-su-taboru-kuris-sugriautas-be-buldozeriu-18-1317450 Last accessed: 30.09.2020

[84] Tubys, L. (2020). Vilniaus taboro istorija baigta: griaunami namai ir buvusị gyvenimą pasakojančios detalès. 15min.lt. Available at: https://www.15min.lt/naujiena/aktualu/lietuva/vilniaus-taboro-istorija-baigta-griaunami-namai-ir-buvusi-gyvenima-pasakojancios-detales-56-1315476 Last accessed: 30.09.2020

[85] Stankevičius, A. (2020). Baigiamas griauti Vilniaus taboras, tačiau narkotikų prekeiviai ir toliau čia vyksta kaip ị darbą. Lrytas.lt. Available at: https://www.lrytas.lt/lietuvosdiena/aktualijos/2020/05/06/news/baigiamas-griauti-vilniaus-taboras-taciau-narkotiku-prekeiviai-ir-toliau-cia-vyksta-kaip-i-darba-14791319/ Last accessed: 02.10.2020

[86] Romų tabore - savas teismas (2020). 15min.lt. Available at: https://www.15min.lt/video/romu-tabore-savas-teismas-75174 Last accessed: 04.10.2020

[87] Nugriautos paskutinès trobos romų tabore: žmonès skundžiasi neturintys kur gyventi (2020). Lrytas.lt. Available at: https:// tv.lrytas.lt/zinios/lietuvos-diena/2020/06/09/news/nugriautos-paskutines-trobos-romu-tabore-zmones-skundziasi-neturintys-kur-gyventi-15213152/ Last accessed: 05.10.2020

[88] Europos Komisija įvertino Lietuvos pažangą romų integracijos procese. (2019). 15min.lt. Available at: https://www.15min.lt/ naujiena/aktualu/lietuva/europos-komisija-ivertino-lietuvos-pazanga-romu-integracijos-procese-56-1200966 Last accessed: 07.10 .2020

[89] Romų tautybės Rasma: „Patyrusi tiek daug rasizmo ir neteisybès, lietuvius turèčiau laikyti savo priešais“ (2019). 15min.lt. Available at: https://www.15min.lt/naujiena/aktualu/lietuva/romu-tautybes-rasma-patyrusi-tiek-daug-rasizmo-ir-neteisybes-lietuvius-tureciau-laikyti-savo-priesais-56-1211690 Last accessed: 09.10.2020

[90] Romų tautybės panevėžietė prabilo apie patirtas kančias ir pažeminimus (2019). Lrytas.lt. Available at: https://www.lrytas.lt/gyvenimo-budas/likimai/2019/10/15/news/romu-tautybes-paneveziete-prabilo-apie-patirtas-kancias-ir-pazeminimus-12195445/ Last accessed: 10.10 .2020

[91] Neapykantos incidentai vis dar išlieka opi problema (2020). Lrytas.lt. Available at: https://www.lrytas.lt/lietuvosdiena/aktualijos/2020/02/25/news/neapykantos-incidentai-vis-dar-islieka-opi-problema-13766120/ Last accessed: 10.10.2020 